\title{
THE CHILDREN OF SCIENCE: \\ People, Property, or Something in Between?
}

\section{Table of Contents}

Introduction............................................................................ 2

I. Three Accepted Classifications for Embryos.................................................. 6

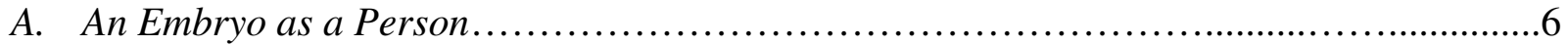

B. An Embryo as a Potential Person ....................................................... 7

C. An Embryo as Property............................................................... 7

II. Insufficiency of Characterizing an Embryo as a Complete Person or Mere Property. 9

A. Arguments Against Personhood .................................................... 9

B. Arguments Against Property................................................. 10

III.A Hybrid Approach of Potential Persons with Due Respect............................ 13

A. Two Different Interpretations of "Potential Person" ................................. 13

B. The Advantages of Embryos as Persons With Limited Rights.............................. 14

IV.Scientific Implications....................................................................... 17

A. The Science Itself: Medical Technologies of Yesterday and Today...................... 17

$i . \quad$ In Vitro Fertilization......................................................... 18

ii. Embryonic Stem Cell Research........................................................23

a. Traditional ES Cell Culture................................................. 24

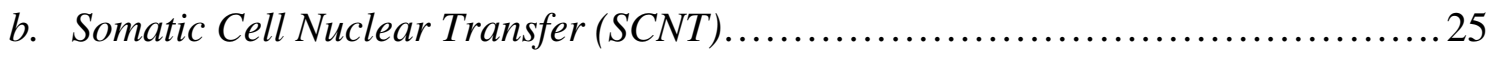

c. Single Cell Biopsy of Eight-Cell Embyo ....................................27

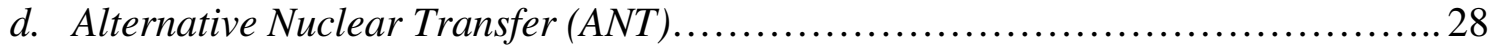

B. Regulating the Science in Light of the Potential Person................................ 30

$i$. In Vitro Fertilization.......................................................... 30

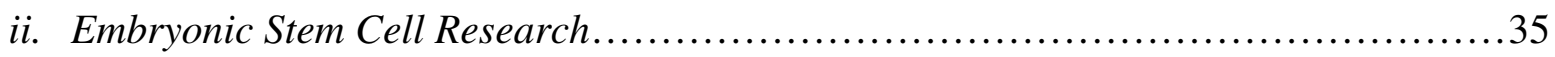

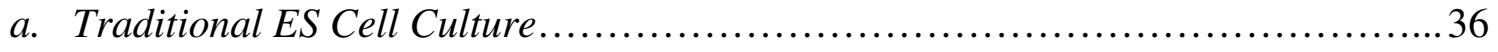

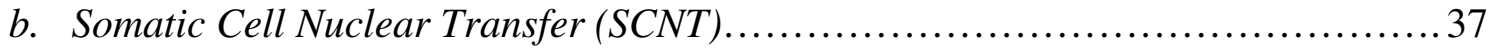

c. Single Cell Biopsy of Eight-Cell Embryo.....................................41

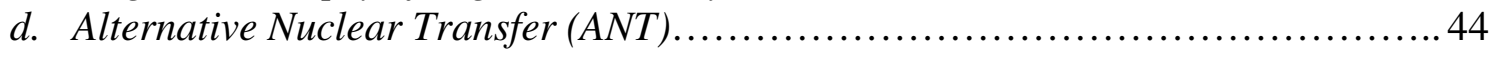

Conclusion.............................................................................. 48 


\title{
THE CHILDREN OF SCIENCE:
}

\section{PROPERTY, PEOPLE OR SOMETHING IN BETWEEN?}

\author{
by \\ Star Lopez ${ }^{*}$
}

\section{INTRODUCTION}

How should states classify embryos? The war has often waged between two classifications, people versus property. But what if a state assumed something in between, finding the embryo to be a potential person entitled to special respect? If a state adopted this position, how would the law affect medical research? Consider the following scenarios:

1. During in vitro fertilization (IVF), physicians cultivate excess embryos that are frozen to be used in future pregnancies. $^{1}$

2. Several embryos are cultivated for IVF, but once one is successfully implanted, the others are destroyed.

3. An IVF patient donates her surplus of embryos to an infertile couple.

4. An IVF patient donates her surplus of embryos to medical research. ${ }^{2}$

\footnotetext{
${ }^{*}$ Star Lopez is a J.D. Candidate at UCLA School of Law for the year 2007. She earned her master's degree in Christian Apologetics from BIOLA University and her bachelor's degree in Political Science from the University of California, Irvine. In regards to this paper, she would like to thank first and foremost her husband, Cpl. Christopher Ryan Smith, for his encouragement, feedback, and support. Next, she would like to thank her faculty mentor, Professor Stephen Munzer, for inspiring her to do this piece and for sharing his wealth of knowledge with her throughout the writing process. She also thanks the UCLA Constitutional Law Writing Circle for all of their brainstorming and editing feedback. In addition, Star gives a special thanks to Professor Eugene Volokh for founding the Writing Circle and Kathleen Holtz for her individual review of the article. Finally, she thanks Glen Liu of Loyola Law School for his outstandingly helpful and in-depth critique of the finished product.

${ }^{1}$ David I. Hoffman, Gail L. Zellman, C. Christine Fair, Jacob F. Mayer, Joyce G. Zeitz, William E. Gibbons, and Thomas G. Turner, Jr., Cryopreserved Embryos in the United States and their Availability for Research, 79 FERTILITY AND STERILITY 1063 (2003).
} 
5. Researchers gather stem cells from a regular embryo that has inherent potential to develop into a baby. ${ }^{3}$

6. Researchers harvest stem cells from a cloned embryo that is capable of surviving past birth. ${ }^{4}$

7. Researchers take stem cells from a single cell of an eight-cell embryo that may or may not be able to survive birth. ${ }^{5}$

8. Researchers collect stem cells from a cloned embryo thatlacks the capacity to implant in the womb and develop into a human baby. ${ }^{6}$

While the use of embryos in medical research has consistently proven controversial, recent medical advances, including single cell biopsies and alternative nuclear transfer (ANT), call for a reconsideration of the embryo and its value in human society. Some individuals contend embryos constitute complete persons while others maintain that embryos merely equate property. However, the American Society for Reproductive Medicine (ASRM) has consistently classified embryos not as persons, but merely as potential human beings worthy of special respect. ${ }^{7}$ Similarly, the United States government has regarded an embryo as something less than a human person. ${ }^{8}$

Although the debate over embryonic status has generally been framed as person versus property, the issue may be more accurately defined as the embryo constituting neither person nor property, but a potential person due special respect. Those who attribute personhood to the embryo contend that embryos

\footnotetext{
${ }^{2}$ Ethics Committee of the American Society for Reproductive Medicine, Donating Spare Embryos for Embryonic Stem-Cell Research, 82 FERTILITY AND STERILITY S224, S225 (2004).

${ }^{3}$ Donald W. Landry and Howard A. Zucker, Embryonic Death and the Creation of Human Embryonic Stem Cells, 114 JOURNAL OF CLINICAL INVESTIGATION 1184 (2004).

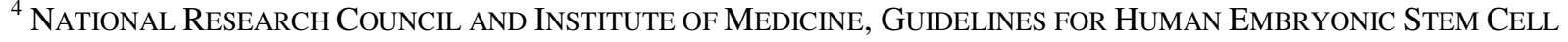
RESEARCH 28 (May 2005).

${ }^{5}$ Young Chung, Irina Klimanskay, Sandy Becker, Joel Marh, Shi-Jian Lu, Julie Johnson, Lorraine Meisner \& Robert Lanza, Embryonic and Extraembryonic Stem Cell Lines Derived from Single Mouse Blastomeres, NATURE LETTERS, October 16, 2005.

${ }^{6}$ Alexander Meissner and Rudolf Jaenisch, Generation of Nuclear Transfer-Derived Pluripotent ES Cells from Cloned Cdx2-Deficient Blastocysts, NATURE 1 (2005), available at http://www.nature.com/nature/journal/vaop/ncurrent/abs/nature04257.html.

${ }^{7}$ Ethics Committee of the American Society for Reproductive Medicine, supra note 2.

${ }^{8}$ Planned Parenthood of Southeastern Pennsylvania v. Casey, 505 U.S. 833, 870 (1992).
} 
ought to share in the rights afforded to all people, including unalienable rights of life and liberty. ${ }^{9}$ On the other hand, people who think of embryos as mere cells, lacking in personhood, believe that an embryo does not warrant any rights whatsoever. Even so, the ASRM and courts, such as that in Davis v. Davis, have found embryos to constitute potential persons owed special respect. ${ }^{10}$ Individuals who regard embryos as potential persons believe that the embryo lacks the requisite individuality for complete human rights yet is entitled to due consideration, or special respect. ${ }^{11}$

Presuming embryos constitute potential persons, the debate continues with how to define "special respect." The status of a potential person runs along a spectrum between property and personhood. How one defines "special respect" determines where the potential person falls along this spectrum. Special respect creates a spectrum of treatment that extends from a property-like limitation of ownership rights to something resembling rights afforded to an absolute person.

Currently, without the protection of a person's human rights, embryos may be dissected, discarded, and donated. Effectually affording embryos special respect, the legislature currently prohibits ther sale and limits their use in experimental research to embryos that have developed for 14 days or less ${ }^{12}$ This rendition of special respect seems to define the potential person as closer to the property end of the spectrum where one treats an embryo as property that offers a limited bundle of rights, i.e. some but not all ownership rights. The embryo donor retains a "bundle of rights," including the right to use, possess, destroy, or alienate by donation. ${ }^{13}$ However, the owner is denied a single stick of the bundle, alienability by sale.

On the other hand, one might characterize special respect as something analogous to limited human rights, identifying the potential person more closely to a person than property. In effect, one might find that an embryo holds a right to life but lacks entitlement to other traditional rights and liberties.

\footnotetext{
${ }^{9}$ Ethics Committee of the American Society for Reproductive Medicine, supra note 2; See also DECLARATION OF INDEPENDENCE [II 2] (1776).

${ }^{10}$ Id. at S224; See also Jennifer Hodges, Comment, Thursday <CSQ>S Child: Litigation over Possession of Cryopreserved Embryos as a Call for Legislation, 40 SANTA CLARA L. REV. 257, 263-64 (1999).

${ }^{11}$ Ethics Committee of the American Society for Reproductive Medicine, supra note 2, at S224.

${ }^{12}$ Ethics Committee of the American Society for Reproductive Medicine, supra note 2; George P. Smith, II, Assisted Noncoital Reproduction: A Comparative Analysis, 8 B.U. INT'L L.J. 21, 36 (1990).

${ }^{13}$ See generally STEPHEN R. MUNZER, A THEORY OF PROPERTY 15 (1990).
} 
Weighing these two interpretations of a "potential person" entitled to "due respect," society may prove more amenable to regarding an embryo as a person with limited rights.

This comment contends that potential personhood may, and perhaps should, result in treating an embryo more like a person afforded limited rights as opposed to property offering its owner a limited bundle of rights. Treated as a person with limited rights, the embryo would retain a right to potential life. Suchreatment would also preserve human dignity and prevent the commodification of human life.

In this comment, we theorize about the impact of a state that statutorily regards an embryo as a potential person. Such a statute may assert that embryonic material with the active potential to develop into a live born offspring, if positioned in the uterus of a woman, is a potential person due special respect that parallels the most fundamental human right to life. ${ }^{14}$ In other words, special respect would afford the potential person a right to its potential life. Such a right draws into question the common practice of destroying embryos in IVF and stem cell research.

Part I assesses the current perception of embryos as persons, potential persons afforded due respect, and property. Part II discusses the potential insufficiency of characterizing embryos as persons and property. Part III analyzes various interpretations of the potential person classification, including property that offers its owner a limited bundle of rights and persons who possess limited rights of their own. Part III also explains the value of treating embryos as more akin to persons than property. Part IV reflects on the implications that regarding an embryo as a person with limited rights would have upon medical technology. This includes an analysis on IVF, a consideration of traditional techniques for culturing stem cell lines, and an assessment of the most recent medical advances in deriving embryonic stem cells.

\footnotetext{
${ }^{14}$ R. Alta Charo, Every Cell is Sacred: Logical Consequences of the Argument from Potential in the Age of Cloning, in ClONING AND THE FUTURE OF EMBRYO RESEARCH 85(P. Lauritzen, ed. 2000) (distinguishing between active and passive potential).
} 


\section{PART I:}

\section{THREE ACCEPTED CLASSIFICATIONS \\ FOR HUMAN EMBRYOS}

Generally, people have classified human embryos in one of three different categories, (1) a person, (2) property, or (3) a potential person afforded "special respect." This last category serves as a middle-ground between person and property. Each of these characterizations create different implications for the treatment of embryos. Hence, courts, religious groups and scientists have all struggled with how to characterize an embryo. To better understand the debate, one must familiarize herself with the meaning and implications of each classification.

\section{A. An Embryo as a Person}

Generally, characterizing an embryo as a person entitles the embryo to the same rights and protections afforded to a fully viable, "living and breathing" human being. ${ }^{15}$ Those who ascribe to this view typically consider life to begin at fertilization and consider the status of a person to take effect at such time. ${ }^{16}$ Others believe the status of personhood takes effect 14 days after fertilization. ${ }^{17}$ At this point, the embryo gains individuality and will no longer twin or regress into a nonviable state. ${ }^{18}$

While some people in general society ascribe to the characterization of embryos as persons, religious groups, such as the Catholic Church, have also adopted the view that embryos constitute people, sacred human life worthy of preservation. ${ }^{19}$ The Church believes that from the moment of conception embryonic life has a right to protection. ${ }^{20}$ As an institution, it goes so far as to label the destruction of an

\footnotetext{
${ }_{16}^{15}$ Ethics Committee of the American Society for Reproductive Medicine, supra note 2.

${ }^{16} I d$.

${ }^{17} I d$.

${ }^{18} I d$.

${ }^{19}$ Congregation for the Doctrine of the Faith, Roman Catholic Church, Instruction on Respect for Human Life in its Origin and on the Dignity of Procreation: Replies to Certain Questions of the Day 5, available at www.vatican.va/roman_curia/congregations/cfaith/documents/rc_con_cfaith_doc_19... (last accessed May 24, 2005).

${ }^{20} I d$.
} 
embryo as an "abominable crime." 21 Hence, being a powerful organization, it condemns research on live embryos unless the experiment will not compromise the embryo's life or integrity. ${ }^{22}$ This ban on embryonic destruction proves consistent with the common sentiment among groups that consider embryos to be persons. These groups afford the embryo fundamental human rights, including a right to life.

\section{B. An Embryo as Property}

On the other hand, some groups believe that the embryo comprises mere property. They have no qualms with research that damages the integrity of an embryo and precludes its further development into an eventual human being. Rather, these groups focus their attention on the property rights belonging to the gamete donors, i.e. genetic parents of the embryo. This position has also extended to reasoning used in case decisions. For instance, to determine the fate of a divorced couple's cryopreserved embryos, the appellate court in Davis v. Davis concentrated its reasoning on the parties' property ownership rights as gamete donors. ${ }^{23}$ As one of the popular characterizations for embryos, the property theory gives wide latitude for the use of embryos in in vitro fertilization and stem cell research.

\section{An Embryo as a Potential Person Afforded Special Respect}

Between the personhood and property theories, lies the depiction of an embryo as a potential person afforded special respect. This theory asserts that researchers must treat an embryo with more care than that applied to mere property, because it has an inherent capability to develop into a human being. ${ }^{24}$ Still, the potential personhood theory falls short of classifying the embryo as a full person and entitling it to all human rights and liberties. ${ }^{25}$

\footnotetext{
${ }^{21} I d$.

${ }^{22} I d$.

${ }^{23}$ Hodges, supra note 10, at 267-268.

${ }^{24}$ Ethics Committee of the American Society for Reproductive Medicine, supra note 2.

${ }^{25}$ Id.
} 
Some theorists, such as Peter Singer and Deane Wells, criticize the potential personhood classification as being overly inclusive, since a separate sperm and egg have equal potential to develop into a person as long as left unimpeded. ${ }^{26}$ However, this comparison fails. A sperm or egg by itself will never develop into a fetus and live offspring. Even a sperm and egg within range of each other will not form an independent life form, unless the sperm manages to break through the outer wall and fertilize the egg. Rather, for bodily tissue to acquire the inherent capacity for independent life, a chemical reaction of fertilization must take place to set the developmental process in motion.

The implication of the potential personhood theory depends on how one defines "special respect." The American Society for Reproductive Medicine (ASRM) and other groups have adopted the potential personhood theory. ${ }^{27}$ Even IVF patients who have cryopreserved their excess embryos can empathize with consid ering them potential persons. In a study, 80 percent of IVF patients were inclined to think of their embryos as a potential child. ${ }^{28}$ Effectually, the ASRM and many IVF patients characterize embryos as potential people worthy of special respect.

However, acceptance of the potential personhood theory by the ASRM and IVF patients holds different implications for each group. The ASRM finds that special respect allows for embryonic research so long as it will likely provide new knowledge benefiting human health. ${ }^{29}$ Regardless of the benefits that embryonic research may offer, IVF patients who thought of their embryos as potential children exhibited apprehension over donating their embryos for research. ${ }^{30}$ One can likely attribute these two different perspectives on embryonic research to the groups' varying degrees of special respect that they afford to the embryo as a potential person.

\footnotetext{
${ }^{26}$ Charo, supra note 14.

${ }^{27} I d$.

${ }^{28}$ A. McMahon, Frances L. Gibson, Garth I. Leslie, Douglas M. Saunders, Katherine A. Porter, and Christopher C. Tennant, Embryo Donation for Medical Research: Attitudes and Concerns of Potential Donors, 18 HUMAN REPRODUCTION 871, 874 (2003). McMahon et al. conducted an experiment consisting of questionnaires distributed to 509 couples who had stored frozen embryos. 152 women $(30 \%)$ responded. $123(24 \%)$ male partners responded. All subjects had embryos stored for 3 months to 12 years. The study demonstrated that few IVF couples were inclined to donate their embryos for research. Only $10 \%$ of the subjects said it is was probable that they would donate surplus embryos for research. $34 \%$ said it was merely possible that they would donate surplus embryos for research. Those with negative views tended to consider embryos as potential children.

${ }^{29}$ Ethics Committee of the American Society for Reproductive Medicine, supra note 2.

${ }^{30}$ McMahon, supra note 28, at 871 .
} 


\section{PART II:}

\section{INSUFFICIENCY OF CHARACTERIZING AN EMBRYO}

\section{AS A COMPLETE PERSON OR MERE PROPERTY}

\section{A. Arguments Against Personhood}

Personhood entitles one to "certain unalienable Rights, ... [including] Life, Liberty and the pursuit of Happiness, ${ }^{, 31}$ and other constitutional rights, such as the right to vote, the right to bear arms, the right to a speedy trial, and other rights. ${ }^{32}$ Though groups of people have widely adopted the personhood theory for embryos, "the unborn have never been recognized in the law as persons in the whole sense." 33 Many people rely on a tangible threshold and define personhood on the basis of birth. However, the theory for embryonic personhood generally requires that fertilization or individuality signal the onset of life.

Some supporters of embryonic personhood may contend that the embryo is a person immediately upon fertilization due to the embryos inherent capacity to develop into a live born human being. Similarly, other supporters use the fourteenth day after fertilization as the dividing line for personhood since the embryo only then achieves individuality. ${ }^{34}$ Prior to the fourteenth day, embryos remain capable of (a) dividing to become twin fetuses or (b) merging with another fertilized oocyte to form a single baby that is a mosaic of genetic patterns. ${ }^{35}$ The only real difference between these two points in development, fertilization and individuality, is that the latter waits to decipher greater specificity in the embryo's potential. Still, both seem to rely on the embryo's inherent capacity for live birth in order to assert personhood.

Opponents contend that capacity for live birth remains insufficient for tissues to qualify as a full person. Since only around 40 percent of all fertilized eggs implant and complete their development,

\footnotetext{
${ }^{31}$ DEClaration OF INDEPENDENCE [I] 2] (1776).

${ }^{32}$ U.S. Const. amend.'s II, VI, IX, XV, XIX.

${ }^{33}$ Roe v. Wade, 410 U.S. 113, 162 (1973).

${ }^{34}$ Charo, supra note 14 , at 84 .

${ }^{35}$ Id.
} 
characterizing every one of them as a full person would constitute a logistical nightmare. ${ }^{36}$ Beyond the issue of practicality, most people do not consider these miscarried embryos as complete human beings. Traditionally, the developmental threshold for a person has been birth, the point at which a fetus can thrive outside the womb.

On the other hand, human beings are "always in a state of evolution toward perfection of [their] potential" Still, no matter their developmental stage, they always qualify as people. For instance, despite some social innuendos, a teenage human being is no less of a person than a forty year-old adult. ${ }^{37}$ However, the embryo's capacity to develop and survive past birth better supports classifying the embryo as a potential person rather than a complete person. Even proponents of embryonic personhood rely on birth as a deciding factor, since they only attribute personhood to human cells with an inherent capacity for developing into live offspring. In which case, it may remain most appropriate to define an embryo as a potential person, which is one with potential to develop into a born human being and worthy of special respect.

\section{B. Arguments Against Property}

In the case of embryos construed as property, the theory does not correspond with human dignity and general social sentiment. Preserving human dignity, the United States government and general society reject the commodification of humanity, which is exemplified by the U.S. ban on slavery. Human tissue also holds unique value over other inanimate objects due to its strong correlation to human persons. Though human tissue is not a person, the United States government prohibits the transfer of human organs for direct payment in order to preserve the dignity of mankind. ${ }^{38}$ While such regulation limits a person's ownership rights over her own body parts, it also reduces the commodification of human tissue and implicitly protects the value of humanity.

\footnotetext{
${ }^{36} I d$.

${ }^{37}$ Id. at 85 .

${ }^{38}$ Ethics Committee of the American Society for Reproductive Medicine, Financial Incentives in Recruitment of Oocyte Donors, 74 FERTILITY AND STERILITY 216 (2000).
} 
Although people have some ownership rights over their body parts like the right to transfer organs by donation, an embryo proves distinct and even worthier of additional consideration. Unlike most body parts and tissue samples, an embryo has the capacity to develop into an independent human being. Not even a gamete cell, the building block for an embryo, can develop into a separate person on its own. This potential for independent human life gives the embryo a deeper connection to personhood. In which case, treating an embryo as mere property that can be bought, sold, and destroyed creates an assault on human dignity, demeaning the importance of human life.

Recognizing this problem, society has cautiously abstained from classifying an embryo as simple property, but instead has given the embryo additional consideration. Even opposing political parties have acknowledged this sentiment. Both Republicans and Democrats have treated human embryos with respect greater than that due typical property. While property owners have a right to destroy their own property, both parties have hesitated in condoning a human embryo's destruction. ${ }^{39}$

Initially, Congress enacted a broad ban on federal funding for human embryonic stem cell research. ${ }^{40}$ As for the Democratic Party, the 1999 Advisory Committee recommended that the government fund both derivation and use of hES cells from spare, donated embryos. Derivation of hES cells requires the destruction of a human embryo and its capacity to develop into a viable human being. ${ }^{41}$ Upon this recommendation, the Clinton Administration hesitated in condoning embryonic destruction and proposed to fund only the use, not derivation, of hES cells. ${ }^{42}$

In 2001 before grants were made, the Republican Bush administration limited consideration of funding to not only the use of hES cells, but also to cell lines derived and cultured before August 9, $2001 .^{43}$ This regulation adopted the theory that the government may condone the medical benefit of stem

\footnotetext{
${ }^{39}$ Ethics Committee of the American Society for Reproductive Medicine, supra note 2, at S224.

${ }^{40}$ Landry, supra note 3.

${ }^{41}$ Ethics Committee of the American Society for Reproductive Medicine, supra note 2, at S224.

${ }^{42} I d$.

${ }^{43} I d$.
} 
cell research so long as it does not cause harm to embryos. ${ }^{44}$ Aside from refusing to fund the derivation of human stem cells, the Bush administration intentionally abstained from providing further incentive for future hES cell derivation. This inter-party sentiment toward embryonic destruction, alongside the interest of preserving human dignity, further amplifies the inadequacy of characterizing embryos as property.

${ }^{44}$ A. Robertson, Causative vs. Beneficial Complicity in the Embryonic Stem Cell Debate, 36 ConneCTICUT LAW REVIEW 1099, 1104 (2004). 


\section{PART III:}

\section{A HYBRID APPROACH OF \\ POTENTIAL PERSONS DUE SPECIAL RESPECT}

\section{A. Two Different Interpretations of "Special Respect"}

According to the potential personhood theory, an embryo is a potential person deserving of special respect. However, this characterization of an embryo remains open for interpretation. While accepting that the embryo constitutes a potential person, groups differ on how to construe "special respect." The spectrum extends from a property-oriented interpretation to a person-oriented understanding. This comment contends that one may most commonly define special respect as either (1) property-oriented with a restriction of the gamete donor's property rights or (2) person-oriented affording an embryo that which reflects a person's most fundamental rights.

To discern the most appropriate meaning of "special respect," we should ask whether the potential person most closely reflects (1) property or (2) person. If a potential person most closely reflects property, then special respect would focus on the property owner's rights and simply restrict these rights to enhance use and perhaps increase the property's preservation. On the other hand, when one closely associates potential personhood with actual personhood, special respect will focus on the embryo's interests. Though a potential person does not share all the rights and liberties of an actual person, an embryo's interests may resemble limited interests akin to some of the most fundamental rights afforded a full human being.

As an example of due consideration that restricts an owner's property rights, the ASRM has adopted the view that an embryo is a potential human being worthy of special respect. ${ }^{45}$ However, the ASRM finds embryonic research ethically permissible if it will likely provide new knowledge benefiting human health. ${ }^{46}$ This treatment of embryos most closely mirrors that of property, such as an animal.

\footnotetext{
${ }^{45}$ Ethics Committee of the American Society for Reproductive Medicine, supra note 2.

${ }^{46} I d$.
} 
Researchers often use animals for research purposes that may lead to their extermination. In a like manner, so long as it is for the greater good, the ASRM allows the researcher to terminate an embryo. Contrary to this notion, society considers human life invaluable and would generally not condone killing a fully viable human being for new knowledge. On the other hand, society will limit an owner's property rights for the sake of advancing medical comprehension. ${ }^{47}$ Adopting a property-oriented definition of potential personhood, the ASRM limits the owner's use of the embryo, rejecting the notion of an embryo's rights and further commodifying the use of an embryo.

When one takes on a person-oriented understanding of the potential person, the embryo's interest takes priority. For instance, many IVF patients also find themselves inclined to view embryos as potential persons worthy of special respect. ${ }^{48}$ Still, this group of patients generally disagrees with donating embryos for medical research. ${ }^{49}$ Effectually, the IVF patient seems to associate potential persons more closely with an actual person than with property. A person-oriented understanding of potential personhood often causes the individual to afford the embryo special respect by attributing to it a human's most fundamental rights. Although a potential person does not have all rights and liberties of an actualized person, the person-oriented understanding would provide it with the most fundamental human right, the right to life. In order to employ any other right or liberty, a person must, first and foremost, be alive. If potential personhood resembles personhood more so than property, then special respect would at the very least preserve the embryo's potential for life.

\section{B. The Advantages of Embryos as Persons With Limited Rights}

Although special respect may be interpreted in two different manners, the person-oriented construction best serves the public interest of holding human life in high regard. Since it has not yet undergone birth and achieved viability outside the womb, the embryo falls short of actual personhood.

\footnotetext{
${ }^{47}$ Moore v. UC Regents, 51 Cal.3d 120, 140-141 (1990) (finding California statutes to limit patient's interest in excised cells, giving the state rights to destroy anatomical parts, human tissues, human remains, or infectious waste). ${ }^{48} \mathrm{McMahon}$, supra note 28.

${ }^{49}$ Id.
} 
Still, it has the inherent capacity to develop into a live born human being. With human embryos having such a close relation to humanity, our treatment of them symbolizes the value of human life.

Applying special respect that affords the embryo a right to its potential life demonstrates that, no matter the degree of potential actually achieved, human life always holds great significance. In a like manner, the disabled and minors, although currently born, fail to achieve the full potential of human abilities or faculties. Though we sometimes limit their rights and freedoms, ${ }^{50}$ we still regard them as persons with protected rights. ${ }^{51}$ Treating these individuals as anything less than a human being would devalue human life in general.

Adopting the person-oriented view of a potential person and interpreting special respect as a limitation on gamete donor's property rights would fail to acknowledge an embryo's unique capacity for life. Even the ASRM admits that embryos constitute more than human tissue. ${ }^{52}$ Because human tissue and organs are property with a limited bundle of rights, ${ }^{53}$ the ASRM's definition would mean that the embryo is more than property offering its owner a limited bundle of rights, i.e. more than the propertyoriented definition of special respect.

The property-oriented view of potential personhood and special respect also violates public policy by commodifying humanity. Because society so greatly values human life and seeks to preserve this high regard, the government has prohibited the commodification of people through slavery. While the prohibition of slavery prevents the commodification of actual persons, the government has extended this preventative measure to property closely associated with humanity. For instance, a person may not transfer human tissue for direct payment. ${ }^{54}$ Though such measures are in part due to an attempt to protect the donor from health risks, they are also intended to discourage the commodification of actual persons by

\footnotetext{
${ }^{50}$ The fact that a person cannot vote until she reaches the age of majority exemplifies a restriction placed on a person's constitutional rights when she is a minor. Furthermore, in a majority of states, a disabled person who is found legally incapacitated and assigned a guardian loses her right to vote. Joan L. O'Sullivan, Role of the Attorney for the Alleged Incapacitated Person, 31 STETSON L. REV. 687, 693 (2002).

${ }^{51}$ For instance, Congress has passed the Americans with Disabilities Act to protect the rights and freedoms of certain disabled people. See 42 U.S.C. $\S \S 12101-12213$ (2006).

${ }^{52}$ Id. at 871 .

${ }_{54}^{53}$ Ethics Committee of the American Society for Reproductive Medicine, supra note 38.

${ }^{54} I d$.
} 
giving consideration to material closely related to human life. Because embryos share a significant connection to fully viable people, treating them as something akin to property would imply that people may be reducible to mere commodities and undermine the preservation of human dignity.

Despite the advantages and disadvantages of these two constructions, this comment simply addresses the implications of defining an embryo under the person-oriented definition. The next section will offer a discussion of how the scientific community has used embryos in medical advancements and research. Although many of the resulting ethical concerns hinge on when life begins, the analysis will focus on the consideration of embryos as potential persons with protected interests and the legal implications of such regard. 


\section{PART IV:}

\section{SCIENTIFIC IMPLICATIONS}

Since the federal government has generally remained unwilling to regulate the disposition of embryos prior to implantation, the states have the discretion to statutorily govern the use of these organisms. ${ }^{55}$ In this analysis, we shall presume that the state has statutorily defined embryos as potential persons and affords the embryos special respect, i.e. protection of their capacity for life.

\section{A. The Science Itself: Medical Technologies of Yesterday and Today}

To understand the scientific use of embryos, one must understand the structure and development of the embryo itself. Basic components necessary for the derivation of an embryo include two cells, the egg and sperm. The egg cell, also known as an oocyte, derives from the female parent. The male parent provides the sperm cell. For an embryo to form, the sperm must fertilize the oocyte. Once this chemical reaction occurs, the embryo commences development.

Initially, a fertilized oocyte results in a single-celled zygote. ${ }^{56}$ This zygote divides to create an embryo. ${ }^{57}$ After three or four days of division, the embryo is deemed a morula and has 16 to 32 cells. ${ }^{58}$ Five to six days after fertilization, the embryo reaches the blastocyst stage and contains 200 to 250 cells. $^{59}$ The blastocyst has an outer layer of cells called the trophectoderm, a fluid-filled cavity known as the blastocoel, and a cluster of cells in its interior termed the inner cell mass (ICM). ${ }^{60}$ While the trophectoderm creates the placenta, the ICM creates the embryonic disk and eventually the fetus. ${ }^{61}$ On

\footnotetext{
${ }^{55}$ Karen Kaplan, No Embryos Lost to New Stem Cells, Los ANGeles Times (October 17, 2005), available at http://www.latimes.com and http://www.stemcellnews.com/articles/stem-cells-no-embryos-lost.htm (last accessed November 28, 2005)(providing an example of California legislation that provides for embryonic stem cell research with state funds).

${ }^{56}$ NATIONAL RESEARCh COUNCIL AND InSTITUTE OF MEDICINE, supra note 4, at 24.

${ }^{57} \mathrm{Id}$.

${ }^{58} I d$.

${ }^{59} \mathrm{Id}$.

${ }^{60} \mathrm{Id}$.

${ }^{61} I d$.
} 
day six, the blastocyst implants in the uterus and the inner cell mass begins differentiation to create embryonic tissue layers for the fetus. ${ }^{62}$

While in utero fertilization has served as the natural reproductive process for many years, the scientific community has recently made significant advances in reproductive technology, in some cases changing the fundamental nature of an embryo. Scientists have used these technological advances in various ways, from helping infertile couples bear children to studying and treating bodily disease. ${ }^{63}$ The following will give a brief introduction to these scientific techniques and their practical value to society.

\section{i. In Vitro Fertilization}

In the 1970's, scientists developed a procedure called in vitro fertilization (IVF). ${ }^{64}$ IVF makes reproduction possible for infertile couples, who have low sperm motility, fail to produce ova, or have physical damage to the fallopian tube or uterus. ${ }^{65}$ IVF allows an infertile couple to bear a child genetically related to them. Rather than adopting, people with infertility problems may beget a child of their own. ${ }^{66}$ The general process requires (1) extraction of the gamete cells, (2) fertilization of the oocyte in vitro, and (3) implantation of resulting embryos into the uterus. ${ }^{67}$

To extract the necessary oocytes, scientists most commonly use ultrasound transvaginal extraction, a non-surgical procedure. ${ }^{68}$ Sedating the donor, the physician punctures a needle through the vaginal wall into the ovaries and extracts follicular fluid which contains the desired oocytes. ${ }^{69}$ Although ultrasound transvaginal extraction is the least invasive method, it proves more difficult and results in fewer oocytes than other surgical procedures. ${ }^{70}$

\footnotetext{
${ }^{62} I d$.

${ }^{63}$ Hodges, supra note 10, at 260; See NATiOnAl ReSEARCh CounCil AND Institute OF Medicine, supra note 4, at 27-28.

${ }^{64} I V F$, BBC NEwS - HEALTH MEDICAL Notes (March 31, 1999), available at http://news.bbc.co.uk/1/hi/health/medical_notes/308662.stm (last visited November 27, 2005).

${ }^{65}$ Hodges, supra note 10 , at 260.

${ }^{66} I d$. at 260 .

${ }^{67} I d$. at $260-261$.

${ }^{68}$ Overview for IVF Patients, GEORGIA REPRODUCTIVE SPECIALISTS (2005), available at http://www.ivf.com/overview.html (last accessed November 27, 2005).

${ }^{69} I d$.

${ }^{70}$ Hodges, supra note 10, at 261.
} 
Upon extracting the follicular fluid, the embryologist locates the oocytes and fertilizes them by one of two methods, microdroplet or ICSI fertilization. ${ }^{71}$ In microdroplet fertilization, the embryologist mixes the oocyte with 150,000 to 225,000 sperm cells, allowing them to penetrate the oocyte on their own. ${ }^{72}$ When male infertility remains a factor, ICSI requires the embryologist to manually inject a single sperm cell into the oocyte. ${ }^{73}$ During and after fertilization, the embryologist maintains the embryos in laboratory dishes that simulate the environment in utero. ${ }^{74}$ Once fertilized, the resulting embryo will dividetwo or three times prior to implantation. ${ }^{75}$ At which point, the physician transfers the cultured embryos into the patient's or surrogate's uterus via catheter. ${ }^{76}$

Although this may seem like a straightforward procedure, it creates far more ethical and medical complications than one might anticipate. First of all, IVF often results in the creation of excess embryos outside the womb. ${ }^{77}$ In case the initial set of embryos fail to implant, this surplus is cryopreserved and later used to repeat the procedure. ${ }^{78}$ Throughout the world, thousands of embryos have been cryopreserved. ${ }^{79}$ At the end of 2000, Australia alone had 71,776 cryopreserved embryos. ${ }^{80}$ As of April 2002, the United States had nearly 400,000 embryos in storage, ${ }^{81}$ and this number increases on a daily basis.

Though most people store their embryos for use in future IVF procedures, these surplus embryos will often exceed the number of embryos necessary to fulfill the couple's reproductive needs. ${ }^{82}$ These embryos share an equal potential to implant in the uterus and develop into a live born offspring. However, when the couple's fertility needs are met, the couple may decide between (1) donating the

\footnotetext{
${ }^{71}$ In Vitro Fertilization (IVF-ET), GEORGIA REPRODUCTIVE SPECIALISTS (2005), available at http://www.ivf.com/ivffaq.html (last visited November 27, 2005); See also Andrology University of Utah Clinical Services: IVF (2001), available at http://uuhsc.utah.edu/andrology/clinical_services_2.html (last accessedNovember 27, 2005).

${ }^{72}$ Andrology University of Utah Clinical Services: IVF, supra note 71.

${ }^{73}$ Id.

${ }^{74}$ In Vitro Fertilization (IVF-ET), supra note 71

${ }^{75}$ Id.

${ }^{76}$ Hodges, supra note 10, at 261.

${ }^{77}$ Ethics Committee of the American Society for Reproductive Medicine, supra note 2, at S226.

${ }^{78} I d$.

${ }^{79}$ McMahon, supra note 28, at 871 .

${ }^{80} I d$.

${ }^{81}$ Jessica Berg, Owning Persons: The Application of Property Theory to Embryos and Fetuses, 40 WAKE FOREST LAW REVIEW 159 (2005); Hoffman, supra note 1, at 1068.

${ }^{82}$ Ethics Committee of the American Society for Reproductive Medicine, supra note 2, at S226.
} 
embryos for biomedical research, (2) donating the embryos to another infertile couple, or (3) discarding the embryos entirely. ${ }^{83}$ Similarly, a couple may elect between one of these three options in case of death, divorce or no further contact with the clinic. ${ }^{84}$ Hence, IVF procedures may often result in the disposal of a human embryo that has the inherent capacity to develop into a live born baby if given an opportunity to implant within a uterus.

Additionally, IVF procedures are costly and endanger the oocyte donor. ${ }^{85}$ IVF procedures can range from $\$ 8,800$ to a little under $\$ 50,000$ for gestational surrogacy. ${ }^{86}$ Furthermore, oocyte donation procedures create risks for the donor. Risks to third party oocyte donors include both physical ${ }^{87}$ and psychological burdens, as well as unintentional pregnancy due to discontinued use of contraceptives. ${ }^{88}$ More extreme risks include disease, remote mortality, impaired fertility, and psychological consequences from waiving parental rights and future contact with resulting children. ${ }^{89}$ Pre-existing IVF patients may endure even more risks, including insufficient oocytes for the patient's own purposes and a psychological

\footnotetext{
${ }^{83}$ Id.; See McMahon, supra note 28, at 872; See also Bernard Lo, Vicky Chou, Marcelle I. Cedars, Elena Gates, Robert N. Taylor, Richard M. Wagner, Leslie Wolf, and Keith R. Yamamoto, Informed Consent in Human Oocyte, Embryo, and Embryonic Stem Cell Research, 82 FerTiLITY AND STERILITY 559-63 (2004). Lo identifies the options that IVF patients in California have in deciding what to do with their excess embryos. Currently, California law requires clinics to offer four options for unused embryos, (1) donating the embryo for medical research, (2) donating the embryo for implantation for another individual, (3) discarding the embryo and allowing it to succumb, (4) storing the unused embryos.

${ }^{84}$ Ethics Committee of the American Society for Reproductive Medicine, supra note 2, at S226.

${ }^{85}$ Fertility Evaluation and Procedures, THE FERTILITY InstiTUTES (2005), available at http://www.fertilitydocs.com/fertility_fees.phtml (last accessed November 27, 2005).

${ }^{86} \mathrm{Id}$.

${ }^{87}$ Both third parties and IVF patient donors who undergo egg retrieval commonly confront physical dangers, such as ovarian hyperstimulation syndrome (OHSS). OHSS is a common response to superovulation and ovulation induction therapy used in IVF. Practice Committee of the American Society for Reproductive Medicine, infra note, at S81. In culturing oocytes, doctors use fertility drugs to cause unusually high egg production and allow control over timing of ovulation. Hodges, supra note 10, at 260. Superovulation is a means of producing multiple eggs, anywhere from 15 to 40 eggs per cycle. Id. Symptoms of OHSS typically arise after superovulation cycles or oocyte retrieval in ART cycles. Practice Committee of the American Society for Reproductive Medicine, supra note 188, at S81. Numerous oocyte retrievals increase the patient's risk of exhibiting OHSS. Id.

Minor Symptoms of OHSS include lower abdominal pain, diarrhea, mild nausea, vomiting, and abdominal distension. Id. at S82. As the illness progresses, the donor may exhibit rapid weight gain and difficulty breathing. Id. In terms of life threatening complications, OHSS may cause kidney failure, adult respiratory distress syndrome, hemorrhaging from an ovarian rupture, and thrombembolisms. Id. Where OHSS symptoms exist, cryopreservation of in vitro embryos may be necessary to defer transfer and decrease the risk of developing severe OHSS symptoms. $I d$. Recurring in half of the women undergoing gonadotropin-induced superovulation cycles, OHSS remains a serious risk to oocyte donors in IVF procedures. Id. at S84.

${ }^{88}$ Ethics Committee of the American Society for Reproductive Medicine, supra note 38. ${ }^{89} I d$.
} 
burden if she remains childless while another couple raises her biological offspring. ${ }^{90}$ Moreover, a preexisting IVF patient who donates her oocytes may bear an increased risk of physical harm from added egg retrieval. ${ }^{91}$

Other factors, including research and financial incentive, may further exacerbate the physical and psychological risks to gamete donors. Incentive to help in medical research may cause donors to subject themselves to more oocyte retrievals than necessary and further exacerbate dangers, such as Ovarian Hyperstimulation Syndrome. ${ }^{92}$ Furthermore, compensation for research participation is common and tends to exacerbate the harm to oocyte donors. ${ }^{93}$ Financial incentives for oocyte donation include monetary payment to third party donors and reduced fees for IVF patients who consent to harvesting excess oocytes for donation purposes. ${ }^{94}$ The monetary benefits to research subjects may provide incentive for donation or simply compensate for risk, time, and inconvenience. ${ }^{95}$

Even when intended as mere compensation, monetary benefits may prove extraordinarily high. By 1999 , the compensation extended from $\$ 2,500$ to over $\$ 50,000 .{ }^{96}$ In fact, entrepreneurial couples may pay relatively large amounts of $\$ 50,000$ or more for oocyte donations from women with specific characteristics and intellectual abilities. ${ }^{97}$ On the other hand, IVF patients who donate excess oocytes have been known to receive 50 to 60 percent reduction in IVF cycle expenses. ${ }^{98}$

\footnotetext{
${ }^{90} I d$.

${ }^{91} I d$.

${ }^{92}$ Ethics Committee of the American Society for Reproductive Medicine, supra note 2, S226.

${ }^{93}$ Neal Dickert, Ezekiel Emanuel, and Christine Grady, Paying Research Subjects: An Analysis of Current Policies, 136 ANNALS OF INTERNAL MEDicine 368 (No. 5, 5 March 2002). The Dickert research study takes a survey of 32 organizations (7 large pharmaceutical companies, 8 contract research organizations (CROs), 8 independent IRBs, 9 academic research centers). The study evaluated each organization's (1) number of clinical research studies originally approved in 1997, (2) quantity of studies that paid subject in that year, and (3) written and unwritten policies on how to compensate research subjects. The results demonstrated $37.5 \%$ of the organizations maintained written policies while all but one had unwritten guidelines. Only $18.8 \%$ of the organizations had the ability to confidently estimate the percentage of studies that pay subjects. In terms of compensation and $87 \%$ of the organizations reimbursed for time. $84 \%$ paid subjects for the inconvenience, $68 \%$ regarded the payment as compensation for travel. $58 \%$ offered payment as incentive to serve as a research subject, but only $32 \%$ identified the monetary payment as compensation for risk incurred. Overall, the researchers found that most organizations compensate research subjects. However, without uniform written standards on compensation, standards vary, and undue inducement may result.

${ }^{94}$ Ethics Committee of the American Society for Reproductive Medicine, supra note 38.

${ }^{95}$ Dickert, supra note 93at 370.

${ }^{96}$ Ethics Committee of the American Society for Reproductive Medicine, supra note 38, at 217.

${ }^{97} I d$.

${ }^{98}$ Id. at 217.
} 
Because no standard guidelines exist for recruitment and compensation among medical research organizations, compensation may result in "uncertain safeguards against unfair or coercive payment." 99 Monetary incentive may induce people to make donations despite a serious risk of harm without full consideration of all the risks and benefits. ${ }^{100}$ Excessively high compensation further exacerbates this problem and preys on the economically deprived. ${ }^{101}$ High monetary payment encourages women, especially women with little money to ignore the risks involved in oocyte donation. ${ }^{102}$ For instance, college newspapers like The Daily Bruin of UCLA advertise compensation ranging from $\$ 5,000$ to $\$ 10,000$ for "a few eggs." 103 Such amounts would cover a student's tuition for a full year. Hence, one might expect an impoverished student to discount the risks of the invasive surgery for one more year's tuition. ${ }^{104}$ Recognizing this problem and attempting to reduce its impact, some organizations limit monetary bonuses to low-risk follow-up visits. ${ }^{105}$

Such compensation may also infringe on human dignity when the payment exceeds the value of time and energy spent by the oocyte donor. Payment may imply a commodification of human genetic material. Since gametes are the primary elements for embryo production, financial incentive for gamete donors raises a serious concern that commodifying human gametes may eventually lead to objectifying embryos and, later, human life. Although U.S. law prohibits the transfer of human organs for direct payment, ${ }^{106}$ this indirect payment for gametes likely exceeds what oocyte donors would be recompensed for hourly time and effort. ${ }^{107}$ Thus, the monetary payment seems to provide consideration for the oocytes themselves, violating human dignity by implicitly putting a price on human body parts.

Overall, IVF remains one of the many advances that the scientific community has made in the use of embryos. While it offers significant advantages to infertile couples, IVF also entails problematic

\footnotetext{
${ }^{99}$ Dickert, supra note 93 , at 368-369.

${ }^{100}$ Id. at 368; Ethics Committee of the American Society for Reproductive Medicine, supra note 38.

${ }^{101}$ Dickert, supra note 93.

${ }^{102}$ Ethics Committee of the American Society for Reproductive Medicine, supra note 38.

${ }^{103}$ Classifieds, THE DAILY BRUIN, October 31, 2005, at 10, col. 2.

${ }^{104}$ Ethics Committee of the American Society for Reproductive Medicine, supra note 38.

${ }^{105}$ Dickert, supra note 93 , at 371.

${ }^{106}$ Ethics Committee of the American Society for Reproductive Medicine, supra note 38.

${ }^{107}$ Id. at 219.
} 
considerations that range from imperiled oocyte donors to the disposal of potential persons and an affront on human dignity. Other innovative scientific techniques give rise to similar and, in some cases, more severe concerns.

\section{ii. Embryonic Stem Cell Research}

Aside from use in reproductive procedures, scientists also utilize embryos in culturing embryonic stem (ES) cells. In the 1980s, scientists first derived ES cells from mouse blastocysts. ${ }^{108}$ The first culture of human ES (hES) cells took place in 1994. ${ }^{109}$ ES cells are primitive, undifferentiated cells taken from the ICM of an embryo blastocyst. ${ }^{110}$ Due to their pluripotent nature, ES cells can differentiate into all body cell types, which provide potential for advancement in therapeutic medicine. ${ }^{111}$ However, extracting hES cells from the blastocyst requires the destruction of the human embryo, which renders hES cell research controversial. ${ }^{112}$

On August 9, 2001, President Bush announced that the government would only fund research on stem cells derived from an embryo created for reproductive purposes prior to August 9, 2001 and donated for research without financial inducement. ${ }^{113}$ Nonetheless, only 20 of these ES cell lines have proven usable, and, out of these 20 lines, all were cultivated on mouse cell feeder layers, which render them imperfect for full therapeutic use. ${ }^{114}$ To better serve regenerative medicine, the therapeutic medical community aims to produce hES cells cultivated on human feeder layers. ${ }^{115}$ However, this requires the destruction of additional embryos that have the ability to produce live born offspring. ${ }^{116}$ Hence, without federal funding, private organizations and individual states continue to fund stem cell research that results in the

\footnotetext{
${ }^{108}$ NATIONAL RESEARCH COUNCIL AND InSTITUTE OF MEDICINE, supra note 4, at 24.

${ }^{109} I d$. at 26.

${ }^{110} \mathrm{Id}$. at 24 .

${ }^{111} \mathrm{Id}$.

${ }^{112}$ Landry, supra note 3.

113 Andrea Flynn, Racial Disparities in the Allocation of Stem Cells, 6 DEPAUL JournAL OF HEALTH CARE LAW 179 (2002).

${ }^{114}$ Kaplan, supra note 55; Irving L. Weissman, Politic Stem Cells, NATURE, October 16, 2005, available at http://www.nature.com/nature/journal/vaop/ncurrent/full/nature04305.html (last visited November 29, 2005).

${ }_{115}^{11}$ Weissman, supra note 114.

${ }^{116} I d$.
} 
termination of further embryos. ${ }^{117}$ For instance, in 2004, California citizens passed Proposition 71, which provided 3 billion dollars for stem cell research. ${ }^{118}$ Despite this private and state funding, scientists continue to seek out new, more effective, and ethically acceptable techniques for culturing hES cells.

\section{a. Traditional ES Cell Culture}

Typical stem cell extraction begins with immunosurgery that removes the embryo's trophectoderm, which is the blastocyst's outer layer of cells. ${ }^{119}$ Then, the ICM located within the blatocoel is disaggregated and implanted on feeder cells. ${ }^{120}$ In isolating the ICM, scientists extinguish the embryo's pre-existing capacity to develop into a live born human being. ${ }^{121}$ Researchers use the ICM to obtain homogenous cell colonies. ${ }^{122}$ Finally, the scientists screen the colonies for stem cells and harvest them for use in medical research. ${ }^{123}$

Embryonic stem cells serve as important therapeutic tools in regenerative medicine. ${ }^{124}$ Since hES cells are self-renewing and scientists can induce them to differentiate into any tissue type, they may be used to study genetic illness and create methods in overcoming tissue rejection. ${ }^{125}$ For instance, scientists may modify hES cells to reduce a person's immune response to tissue transplants, increasing the probability that the patient's body will accept the transplant. ${ }^{126}$ Hence, society has a great interest in accumulating genetically diverse hES cells, so that stem cell research may benefit people of all genetic backgrounds. ${ }^{127}$

However, traditional hES cell cultures require the production of embryos much like that in IVF. In fact, the main source of embryos for ES cell research comes from the surplus embryos created in IVF

\footnotetext{
${ }^{117}$ Kaplan, supra note 55.

${ }^{118} \mathrm{Id}$.

${ }^{119}$ Id.

${ }^{120}$ Landry, supra note 3.

${ }^{121}$ NATIONAL RESEARCH COUNCIL AND INSTITUTE OF MEDICINE, supra note 4, at 24, 26.

${ }^{122} \mathrm{Id}$.

${ }^{123} \mathrm{Id}$.

${ }^{124}$ NATIONAL RESEARCH COUNCIL AND InSTITUTE OF MEDICINE, supra note 4, at 24, 28.

${ }^{125} \mathrm{Id}$. at $27-28$.

${ }^{126} \mathrm{Id}$. at 28 .

${ }^{127} \mathrm{Id}$.
} 
procedures. ${ }^{128}$ Consistent with the very nature of their creation, these embryos have the potential to develop into live born human beings. As a result, hES cell research involves many of the same concerns over human dignity and health risks to gamete donors. To obtain the necessary embryos, ES cell research requires oocyte donors to undergo some psychological and physical risks. Even more, in order to extract hES cells, scientists must destroy the human embryo and its ability to develop into a live born offspring. ${ }^{129}$ Despite these problems, the scientific community forges on in stem cell research in hopes of improving regenerative medicine.

\section{b. Somatic Cell Nuclear Transfer (SCNT)}

Extending their research to stem cells that duplicate the genetic makeup of existing individuals, scientists developed Somatic Cell Nuclear Transfer (SCNT), also known as "cloning." In 1997, Ian Wilmut at Roslin Institute in Scotland achieved nuclear transfer by starving a cell into a reproductively agreeable state and injecting it's nucleus into an enuclearted egg. ${ }^{130}$ As a result, Dolly the Sheep, the first mammal clone, came into being. ${ }^{131}$ In early 2005, Dr. Hwang Woo Suk of South Korea claimed to have derived human ES cells via SCNT. ${ }^{132}$ However, late that year, it was found that Hwang had fabricated his discovery. ${ }^{133}$ The Herald Tribune called it the "most sensational case of scientific fraud in recent history." 134

The SCNT process produces an embryo-like organism, called an embryoid, which is an exact genetic match to a currently viable being. ${ }^{135}$ Instead of fertilizing an oocyte with a sperm cell, a

\footnotetext{
${ }^{128}$ Robertson, supra note 44, at 1099.

${ }^{129}$ Landry, supra note 3.

${ }^{130}$ H. Rhodes, The Difficulty of Regulating Reproductive and Therapeutic Cloning: Can the United States Learn Anything from the Laws of Other Countries? 21 PENN STATE INTERNATIONAL LAW REVIEW 341, 343 (2003).

${ }^{131}$ Id. at 132.

${ }^{132}$ Erika Check \& Carina Dennis, Ethical Routes to Stem Cells Highlight Political Divide: Split Opens over Methods to Create Nonviable Embryos, NATURE, October 16, 2005 (on-line) (accessed through News@ nature.com at http://www.nature.com/news/2005/051010/pdf/4371072b.pdf).

${ }^{133}$ S Korea Cloning Research was Fake, BBC NEWs, December 23, 2005 (on-line) (accessed through http://news.bbc.co.uk/go/pr/fr/-/1/hi/world/asia-pacific/4554422.stm).

${ }^{134}$ Choe Sang-Hun and Elisabeth Rosenthal, Research in Cloning Declared a Fabrication, INTERNATIONAL HERALD TRIBUNE, December 23, 2005 (on-line) (accessed through http://www.iht.com/articles/2005/12/23/news/clone.php).

${ }^{135}$ Weissman, supra note 114; NATIONAL RESEARCH COUNCIL AND InstituTE OF MEDiCinE, supra note 4.
} 
researcher electrically shocks the nucleus of a specialized cell, such as a skin cell. ${ }^{136}$ Then, the researcher injects the nucleus into the cytoplasm of an enucleated oocyte. ${ }^{137}$ Finally, the egg is activated to divide and form a blastocyst that replicates the genetic makeup of the nucleus donor. ${ }^{138}$

Similar to a traditional embryo, the resulting embryoid has the inherent potential to implant in the uterus and to develop into a live born person. ${ }^{139}$ However, these offspring often exhibit abnormalities. Cloned mammals have a low survival rate and most do not survive past birth. ${ }^{140}$ In fact, those that survive exhibit significant genetic defects, such as large offspring syndrome. ${ }^{141}$ Large offspring syndrome results in respiratory and metabolic abnormalities as well as an enlarged and dysfunctional placenta. ${ }^{142}$ Even if abnormalities fail to appear at birth or younger ages, cloned offspring have shown signs of defective metabolisms and pathological alterations in organs. ${ }^{143}$ Likewise, the first cloned mammal, Dolly the sheep, died prematurely exhibiting pathological abnormalities. ${ }^{144}$

Achieving both therapeutic and reproductive cloning, SCNT marks significant advances in medical research. By therapeutic cloning, nuclear transfer permits the collection of ES cells that genetically mirror existing people or animals. ${ }^{145}$ Like traditional ES cells, these cells self-renew and can differentiate into most mature body cells. ${ }^{146}$ Hence, SCNT would theoretically allow scientists to produce exact tissue matches for a patient in need of a transplant. ${ }^{147}$ It even provides a means by which researchers can study the cause, development and effects of a donor's complex genetic disease. ${ }^{148}$ SCNT

\footnotetext{
${ }^{136} \mathrm{Id}$.

${ }^{137}$ NATIONAL RESEARCH COUNCIL AND InSTITUTE OF MEDICINE, supra note 4.

${ }^{138} \mathrm{Id}$.

${ }^{139}$ Charo, supra note 14 , at 86.

${ }^{140}$ Rudolf Jaenisch, Human Cloning -- The Science and Ethics of Nuclear Transplantation, 351N EW ENGLAND JOURNAL OF MEDICINE 2787 (December 30, 2004).

${ }^{141} \mathrm{Id}$.

${ }^{142} \mathrm{Id}$.

${ }^{143} \mathrm{Id}$.

${ }^{144}$ Id.; Charo, supra note 14, at 86.

${ }^{145}$ Rhodes, supra note 130, at 344.

${ }^{146}$ Jaenisch, supra note 140.

${ }^{147} \mathrm{Id}$.

${ }^{148} I d$.
} 
also opens the door to reproductive cloning, the creation of a live born baby thatshares its exact genetic makeup with an already existing person. ${ }^{149}$

While SCNT would offer significant scientific advantages, it still entails potential ethical and practical problems. Like ES cell cultures from a regular embryo, SCNT involves fatal damage to an embryoid with the ability to develop into a live born offspring. ${ }^{150}$ In addition, SCNT not only threatens the commodification of human life by financial solicitation of oocytes, but it also devalues the human individual by making genetic copies of an already existing person, particularly through reproductive cloning. "With larger numbers comes the possibility of declining regard" for the genetic individual. ${ }^{151}$

\section{c. Single Cell Biopsy of Eight-Cell Embryo}

As a solution to some of the ethical concerns that stem cell research invites, scientists at Advanced Cell Technology in Worcester, Massachusetts developed the single cell biopsy of an eight-cell embryo, a new technique for culturing hES cell lines. ${ }^{152}$ The single cell biopsy method imitates an IVF procedure used to diagnose an embryo for any of 150 genetic defects. ${ }^{153}$ Researchers allow an embryo to divide three times over the course of two days after fertilization. ${ }^{154}$ Once the embryo reaches eight cells, a researcher divides it into two, plucking one cell from the embryo and allowing the other seven cells to continue developing. ${ }^{155}$ This dissection occurs immediately before the embryo transforms into a blastocyst. ${ }^{156}$ After extracting the single blastomere, researchers surround the blastomere with hES cells to induce it into behaving like a human stem cell. ${ }^{157}$

\footnotetext{
${ }^{149}$ NATIONAL RESEARCH COUNCIL AND InSTITUTE OF MEDICINE, supra note 4.

${ }^{150}$ Charo, supra note 14 , at 86.

${ }^{151} \mathrm{Id}$. at 88 .

${ }^{152}$ Malcolm Ritter, Studies Show New Ways to Get Stem Cells, October 16, 2005, available at http://www.wjla.com/news/stories/1005/269278.html (last visited December 1, 2005).

${ }^{153}$ Id.; Nicholas Wade, Stem Cell Test Tried on Mice Saves Embryo, NEW YORK TIMES, October 17, 2005, available at http://topics.nytimes.com/top/news/health/diseasesconditionsandhealthtopics/stemcells/?inline=nyt-classifier (last visited November 29, 2005).

${ }^{154} \mathrm{Id}$.

${ }^{155}$ Ritter, supra note 152; Stem Cell Side Shows, NEW YORK TIMES, October 18, 2005, at A2, col. 3.

${ }^{156}$ Wade, supra note 153.

${ }^{157}$ Kaplan, supra note 55.
} 
Stem cells produced via single cell biopsies offer the same medical advantages in therapeutic medicine as ES cells taken from a regular embryo. ${ }^{158}$ Researchers may use these cells to create replacement cells in case of disease. ${ }^{159}$ However, stem cells retrieved by single cell biopsy are limited to the genetic makeup of blastomeres extracted prior to birth. ${ }^{160}$ In other words, this single cell biopsy does not permit the culturing of stem cells that share the genetic makeup of an already existing person. ${ }^{161}$ Furthermore, since it may still utilize surplus embryos from IVF, the procedure does not solve the risks posed to oocyte donors.

Some contend that this single cell biopsy redresses the concern of embryo destruction that arises in traditional hES cell extraction. ${ }^{162}$ Allowing the other seven embryos to continue developing, this procedure attains human stem cells without destroying the original embryo. ${ }^{163}$ Theoretically, this allows researchers to show due respect to embryos as potential persons by allowing them to continue development and possibly survive past birth. ${ }^{164}$ However, a major reservation about the single cell biopsy method is whether or not researchers fail to show due respect by experimentation on the single blastomere. ${ }^{165}$ If the single cell blastomere can develop into a live born offspring on its own, then the method may still undermine human dignity and fail to show special respect to the potential person.

\section{d. Alternative Nuclear Transfer (ANT)}

Looking for a more versatile method that would provide a therapeutic benefit to born individuals and would appease ethical considerations, scientists recently developed a new form of stem cell extraction called alternative nuclear transfer. William Hurlbut, a Stanford professor and a member of President Bush's Council on Bioethics, first proposed the idea in response to a demand for stem cell research that

\footnotetext{
${ }^{158}$ Wade, supra note 153.

${ }^{159} \mathrm{Id}$.

${ }^{160} \mathrm{Id}$.

${ }^{161}$ Stem Cell Side Shows, supra note 155.

${ }^{162}$ Wade, supra note 153.

${ }^{163}$ Id.

${ }^{164}$ Id.

${ }^{165} \mathrm{Id}$.
} 
required more sophisticated stem cells than that funded under Bush's 2001 legislation. ${ }^{166}$ Hurlbut proposed alternative nuclear transfer, a method that derived stem cells from an entity that is inherently unable to develop into a live born human being. ${ }^{167}$

Just recently, Meissner and Jaenisch, researchers from Whitehead Institute for Biomedical Research and MIT, made this theory into a reality, discovering a procedure to achieve ANT. ${ }^{168}$ By suppressing cdx2 expression in the nucleus injected into the oocyte, the researchers created an embryoid inherently incapable of developing into a human offspring. ${ }^{169}$ The cdx2 gene codes for trophectoderm development. ${ }^{170}$ Without cdx2, the embryoid lacks the capacity to develop placenta in the early stages of embryo growth. ${ }^{171}$ Unable to develop placenta, the embryoid cannot develop past the blastocyst stage. ${ }^{172}$ Still, researchers can derive pluripotent stem-cell lines from the embryoid's ICM. ${ }^{173}$ Like classical ES and NT cell lines, these pluripotent cell lines can form several kinds of mature cells. ${ }^{174}$ Although capable of generating most tissues, ANT ES cells that lack cdx2 expression cannot generate intestinal tissue. ${ }^{175}$ Nonetheless, when researchers reactivate cdx 2 expression in the stem cell, the cell can produce all somatic tissues, including intestinal tissues. ${ }^{176}$ ANT stem cell extraction currently works on mice cells and would theoretically apply to human embryos, as well. ${ }^{177}$

As a result, this procedure would offer a new source for harvesting fully human ES cells without destroying a potential person. Since the embryoid biologically cannot implant, it lacks the potential for live human birth. Hence, dissection for ES cultures would not inhibit the embryoid's capacity for human

\footnotetext{
${ }^{166}$ Weissman, supra note 114.

${ }^{167} \mathrm{Id}$.

${ }^{168} I d$.

${ }^{169}$ Id.; See Stem Cell Side Shows, supra note 155; See also Rick Weiss, Mice Stem Cells Made without Harm to Embryos, WASHINGTON POST, October 17, 2005, at A06, available at http://www.washingtonpost.com/wpdyn/content/article/2005/10/16/AR2005101600754.html.

${ }^{170}$ Meissner, supra note 6.

${ }^{171}$ Weiss, supra note 169.

${ }^{172}$ Weissman, supra note 114; See Weiss, supra note 169; See also Stem Cell Side Shows, supra note 155; Meissner, supra note 6.

${ }^{173}$ Weissman, supra note 114; See also Stem Cell Side Shows, supra note 155.

${ }^{174} \mathrm{Id}$.

${ }^{175}$ Meissner, supra note 6, at 2.

${ }^{176}$ Id. at 3.

${ }^{177}$ Check, supra note 132.
} 
personhood. Furthermore, unlike ES cells obtained from single cell biopsies, ANT stem cells may share an identical genetic makeup to that of an already existing patient. ${ }^{178}$ Essentially, ANT stem cells offer the same possibilities for therapeutic medicine as does SCNT cloning without obstructing potential life. Even better, ANT does not raise the SCNT ethical concern of devaluing human life by reproductive cloning. Since the ANT embryoid inherently cannot implant, it cannot achieve reproductive cloning. However, the risks on donors continue to persist under ANT, as well as the potential for commodifying genetic human material, such as oocytes.

\section{B. Regulating the Science in Light of the Potential Person}

Considering the various functions and implications of each of these procedures, we must next consider how an embryo's status as a potential person and right to special respect affects the appropriateness of these practices. Since life, as opposed to death, is generally considered to be in the best interest of a human being, ${ }^{179}$ the United States Constitution identifies life as a fundamental right possessed by every person. ${ }^{180}$ This comment assesses the impact of states classifying embryos as potential persons entitled to special respect. Presuming that the state adopts a person-oriented understanding of potential personhood, the state will afford the embryo special respect akin to the most fundamental human rights, including a person's right to life. Hence, a state adopting a person-oriented approach to potential personhood will likely show due respect by preserving an embryo's potential for life. In other words, the state would prohibit any use of an embryo that eliminates its inherent ability to mature into a living human being.

\section{ii. In Vitro Fertilization (IVF)}

IVF creates embryos with the potential to implant and grow in the patient's womb but often results in the production of more embryos than required by the patient's reproductive needs. ${ }^{181}$ Consistent

\footnotetext{
${ }^{178}$ Ritter, supra note 152.

${ }^{179}$ Hodges, supra note 10, at 265.

${ }^{180}$ U.S. CONST. amend. V; U.S. CONST. amend. XIV, $\$ 1$.

${ }^{181}$ Ethics Committee of the American Society for Reproductive Medicine, supra note 2, at S226.
} 
with their intended use, these embryos have the inherent potential to implant and develop into a live born human baby. ${ }^{182}$ However, many patients fail to implant all of their excess embryos. ${ }^{183}$ When patients divorce, die, or simply fulfill their reproductive needs, they have one of three options (1) donating their embryos to research, (2) donating their embryos to another couple, or (3) discarding the embryo entirely. ${ }^{184}$

Although donating one's embryos for another couple to implant allows the embryo to actualize its potential,inconsistency with the potential personhood theory arises in disposing of the embryo and possibly donating the embryo to medical research. Discarding the embryo and allowing it to succumb essentially destroys the embryo as well as its potential to grow into a live offspring. Similarly, research may require the dissection of an embryo to the point where it loses its ability to implant in the uterus and develop into a living baby. In which case, such donation would violate the underlying rule of prohibiting procedures that destroy an embryo's potential for life. Even more, some contend that creating excess embryos for destruction and experimentation immorally exploits the embryo as "disposable "biological material." ${ }^{185}$ Such exploitation runs contrary to the special respect due to a potential person, and should not be allowed.

Others would contend that the mere cryopreservation as opposed to immediate implantation exposes embryos to a risk of harm and temporary deprivation of maternal shelter and gestation. ${ }^{186}$ However, this comment does not extend its position to that length, since special respect ought to reflect the most fundamental of human rights and must not be abused as a free-for-all of protection. Unlike destruction, potential risk of harm and temporary deprivation of opportunity to gestate does not conclusively deprive the embryo of the opportunity to develop into a live born human offspring. Even so,

\footnotetext{
${ }^{182} I d$.

${ }^{183} \mathrm{Id}$.

${ }^{184}$ Id.; McMahon, supra note 28, at 872.

${ }^{185}$ Congregation for the Doctrine of the Faith, Roman Catholic Church, supra note 19. ${ }^{186} \mathrm{Id}$.
} 
an excessive number of surplus embryos that couples cryopreserve still pose a grave problem where couples complete their treatment and do not want any more children. ${ }^{187}$

Hence, a state that has adopted potential personhood should limit the number of embryos produced to the amount that a couple is willing to implant. In fact, the state ought to require patients to construct an alternative plan of adoption for each unused embryo created in the procedure. This ensures implantation, giving each potential person a reasonable opportunity to develop into a live-born offspring. On another note, this does not limit the number of oocytes cultured but may potentially reduce the number of oocytes needed if the embryologist intends to fertilize fewer eggs.

Others might contend that limiting the number of embryos produced unfairly disadvantages patients whose first set of embryos fail to implant. Cryopreserved embryos that a patient may use later are less likely to result in pregnancy than freshly-cultivated embryos. ${ }^{188}$ Also, any further extraction procedures may prove too expensive for patients to afford. Patients may argue that this risk justifies cryopreserving more embryos than one intends to bear. However, these contentions do not defeat such regulation. Instead, patients may cultivate excess eggs and sperm then freeze them for later fertilization. In case a patient wishes to have more embryos than she anticipated, she may fertilize her excess eggs to create as many embryos as she decides to immediately bear. In case she cannot bear every embryo produced, again she should have alternative parents at her disposal to carry and raise the child.

Furthermore, patients may protest having to make a choice between bearing children that they do not want and giving their embryos to adoptive parents. ${ }^{189}$ However, limiting the number of embryos produced to the number that the patient is willing to raise reduces the severity of this problem, since the patient would have weighed these considerations in advance. If she does not wish to donate her embryos, she may simply limit the amount that she creates and store excess oocytes and sperm for later fertilization, in case she decides to bear more children.

\footnotetext{
${ }^{187}$ McMahon, supra note 28, at 872.

${ }^{188}$ Practice Committee of the American Society for Reproductive Medicine, Ovarian Hyperstimulation Syndrome, 82 FERTILITY AND STERILITY S81, S82 (2004).

${ }^{189}$ Hodges, supra note 10, at 276.
} 
As IVF procedures typically require informed consent, it would place a minimum burden on clinics to require that the couple stipulate the disposition of excess embryos prior to the procedure. ${ }^{190}$ Similar to how some recommend a physician discuss donation with the patient at the initiation of any advanced fertility treatment, ${ }^{191}$ the physician should also discuss the number of children that the patient desires to bear and with whom the patient would want any surplus embryos placed. In case the patient ends the treatment early, her alternative appointment or consent to donation will ensure that the embryo has an opportunity to develop and fully achieve its potential for live birth.

In order to show an embryo "due respect," the state may also prevent its commodification by limiting compensation for gamete donations to minimum wage for time. Generally, society disagrees with commodifying embryos. Even IVF patients who donate their embryos to medical research prefer research toward fertility as opposed to research for patenting or commercial products. ${ }^{192}$ As discussed previously, high compensation for gamete donation imitates a transfer of property by sale. Although law prohibits the buying and selling of embryos, the symbolic relationship between gametes and their embryonic product as well as the transfer of gametes for large sums of money result in commodifying both the gametes and the embryo. Commodification manifests treatment of an embryo as mere property, not a potential person afforded due respect. Hence, such commodification runs contrary to the potential personhood theory and the aims of a state adopting it.

Furthermore, financial incentives may lead to the objectification of live people. Some private parties use financial incentives to generate children with socially desirable traits, effectually objectifying humans as opposed to recognizing their intrinsic value. ${ }^{193}$ Even the Ethics Committee of ASRM acknowledges the problem and recommends that patients be compensated for time and effort, not the number or quality of oocytes retrieved or the donor's ethnic or personal characteristics. ${ }^{194}$ Hence, limiting

\footnotetext{
${ }^{190}$ Hodges, supra note 10 , at 280-81.

${ }^{191}$ Lo, supra note 83.

${ }^{192}$ Lo, supra note 83 , at 560 .

${ }^{193}$ Ethics Committee of the American Society for Reproductive Medicine, supra note 38, at 217.

${ }^{194}$ Id. at 219.
} 
compensation to the minimum wage for one's time and effort would likely reduce objectification of a potential person and result in a remainder of altruistic gamete donations.

In addition, eradicating disproportionate compensation would reduce the risks to gamete donors. Instead of allowing the high compensation to cloud her judgment, a donor will more likely make an informed decision and completely consider the physical and psychological risks involved. This effect will better protect women in a lower socio-economic bracket that remain more susceptible to the undue influence of excessive compensation.

While this reduction in compensation and limitation on embryo production would reduce the number of excess embryos that do not have an opportunity to implant, surplus embryos already in existence still remain a problem. One practical solution would include the strong encouragement for couples to donate their surplus embryos to adoptive parents. However, this retroactive application may violate the couple's right to notice. In which case, the government may decide to permit disposal of the embryo or even donate it to medical research under the theory that one may benefit from the use so long as she does not cause the harm. ${ }^{195}$ The United States and Germany have adopted such a theory to justify using ES cells that were extracted by means of destroying embryos. Although the United States uses federal funds for ES cell research on cell lines produced prior August 2001, the government contents itself with the fact that it did not cause the destruction of the embryo but simply benefited from it. ${ }^{196}$

The state's decision would depend on how heavily it gives credence to special respect due to the potential person. Generally, when a woman has a born child that she no longer wants, she may not terminate the child but has the option of giving the child up for adoption. However, in the interest of her bodily integrity, a woman may freely terminate a fetus before it reaches viability. ${ }^{197}$ Unlike the case of abortion, the continued development of a cryopreserved embryo does not infringe on the woman's bodily integrity. Hence, to remain consistent with the respect owed to a potential person, this logic would advise forced donation over destroying the embryo. Though special respect of preserving a potential person's

\footnotetext{
${ }^{195}$ Robertson, supra note 44.

${ }^{196} \mathrm{Id}$.

${ }^{197}$ Casey, 505 U.S. at 846.
} 
life would not outweigh another person's right to bodily integrity, it would likely outweigh the right to notice, arguably a lesser right than a woman's bodily integrity and an embryo's entitlement to potential life.

Overall, the adoption for the person-oriented conception of embryos as potential persons would allow for the continued yet limited use of IVF. While patients might still employ IVF to create life, the state would probably add protections for the embryo and its potential to develop into a live born offspring. Possible regulations would include limiting the production of embryos to the number that the patient is willing to bear and ensuring the donation of any excess embryos to adoptive parents. In addition, under the property-oriented understanding, the state would probably prohibit the destruction of embryos made prior to the enactment of such regulations and encourage the donation of such embryos to adoptive parents. To decrease the commodification of human life, the state may even regulate the pay scheme for gamete donation, ensuring altruistic motivations and a continued distinction between humanity and property.

\section{ii. Embryonic Stem Cell Research}

On the other hand, a state that accepts the property-oriented understanding of potential personhood would expectedly handle stem cell research in a more direct manner. Instead of producing embryos to give them an opportunity to thrive, the use of embryos in stem cell research focuses on the cultivation of stem cells, which in many cases involves the destruction of an embryo and its potential for life. As noted before, Congress originally banned the federal funding of human embryonic stem cell research. ${ }^{198}$ Today, the federal government funds stem cell research on a limited number of hES cell lines. ${ }^{199}$ However, scientists seek to expand their research to a more genetically diverse test group and to conduct tests on improved hES cells. Such exploits require some form of stem cell extraction which commonly causes the destruction of human embryos from which the researcher removes the cells.

\footnotetext{
${ }^{198}$ Landry, supra note 3.

${ }^{199}$ Ethics Committee of the American Society for Reproductive Medicine, supra note 2, at S224.
} 
Assuming a person-oriented conception of special respect for embryos, a state would generally show respect to an embryo by preserving its potential for life. Depending on the type of procedure and its implications for the embryo's capacity for life, such a state would go so far as to completely prohibit procedures that eliminate an embryo's ability to develop into a live offspring. Society already finds the deliberate creation of embryos for the purpose of destruction reprehensible. ${ }^{200}$ Still, a state adopting the person-oriented view of potential personhood would focus its concern, not on the reason for creation, but the impact that the procedure has on the embryo's inherent ability to develop into a live born offspring. Whether or not the scientists created the embryos for stem cell research, the state that affords an embryo person-oriented respect would protect each embryo's potential for life.

\section{a. Traditional ES Cell Culture}

In traditional stem cell extractions from ordinary embryos, scientists culture the stem cells by removing the trophectoderm and effectually destroying the embryos capacity to develop. ${ }^{201}$ Since the person-oriented theory protects potential human life, it would prohibit the destruction of an embryo's inherent capacity to develop into a live born offspring. Although traditional stem cell extraction results in isolating stem cells, human ES cells alone cannot produce a live born offspring. ${ }^{202}$ Thus, the traditional extraction of stem cells from embryos would annihilate the embryo's ability to mature into a fully viable person and prove impermissible under the person-oriented theory of special respect.

Note, however, the use of stem cells alone does not violate the principle of protecting potential human life. Stem cells by themselves lack the intrinsic ability to develop into a live person. ${ }^{203}$ Although hES cells may possibly produce an embryo if combined with a trophectoderm, ${ }^{204}$ alone they fail to naturally develop into a human being. Rather, the potentiality that stem cells hold is somewhat akin to the capacity of a single gamete. By itself, it cannot naturally grow into a person, but, if combined with

\footnotetext{
${ }^{200}$ McMahon, supra note 28 , at 871 .

${ }^{201}$ National ReSEARCh Council And Institute of Medicine, supra note 4, at 26.

${ }^{202} I d$. at 24.

${ }^{203} \mathrm{Id}$.

${ }^{204}$ Id.
} 
other necessary components, it may attain such potential by transforming into a human embryo. Without an inherent capacity to become an actual person on its own, a stem cell is not a potential person due special respect. On the other hand, a regular embryo used in traditional stem cell extraction has the innate ability to mature into a viable person. Hence, the embryo is a potential person. While stem cells do not require special respect, an embryo may naturally develop into a liveperson, which warrants special consideration and protection of its capacity for life.

As traditional stem cell extraction involves the destruction of an embryo and its ability to develop, some have asserted that scientists may protect an embryo's potential life by extracting stem cells only from defective embryos. Renowned stem cell researchers, Landry and Zucker, theorize about removing ICM from blastocysts declared dead from cleavage arrest with no chance of further development. ${ }^{205}$ However, such a distinction remains difficult to determine and impossible to perfectly identify. ${ }^{206}$ In fact, it would likely result in the accidental termination of an embryo capable of full development into a person. With protection of the potential person in mind, person-oriented special respect would probably not allow for the sacrifice of a potential life but, like treatment of actual human life, take precautions to ensure that the potential life is preserved instead of sacrificed for efficiency and productivity. Overall, a state that adopts a person-oriented understanding of potential personhood would likely ban traditional stem cell extraction altogether.

\section{iii. Somatic Cell Nuclear Transfer}

Similarly, stem cell extraction from SCNT embryoids would also terminate a potential person capable of developing into a live born offspring. ${ }^{207}$ An embryoid of SCNT undergoes similar cell division and development as that of a natural embryo. ${ }^{208}$ However, culturing ES cells from nuclear transfer

\footnotetext{
${ }^{205}$ Landry, supra note 3; NATIONAL RESEARCH COUNCIL AND INSTITUTE OF MEDICINE, supra note 4, at 30.

${ }^{206}$ NATIONAL RESEARCH COUNCIL AND INSTITUTE OF MEDICINE, supra note 4, at 30.

${ }^{207}$ Id. at 28.

${ }^{208}$ Charo, supra note 14 , at 89.
} 
blastocysts requires removing the ICM from the trophectoderm, which destroys the embryoid. ${ }^{209}$ Because the procedure inhibits an embryoid's inherent potential for life, the person-oriented theory would preclude SCNT for stem cell extraction.

On the other hand, some contend that the SCNT embryoids lack full potential for human life since they result in low birth success rates and abnormal offspring. Although SCNT blastocysts may create live-born offspring like a natural embryo, SCNT embryoids have a low success rate for live birth and the resulting offspring often exhibit abnormalities. ${ }^{210}$ In a study of frogs by Byrne et al, tadpole SCNT embryoids rarely attained their full potential, specifically less than one percent of the embryoids developed into actual tadpoles. ${ }^{211}$ Despite a low survival rate, this one percent success rate evidences that some embryoids resulting from SCNT will develop into live born human beings. Unable to discern with complete certainty which will survive and which will not, special respect would give each embryoid an opportunity to thrive as a potential person.

As for arguments that abnormal offspring are not worth preserving, some assert that because an SCNT embryoid lacks the ability to develop into a "healthy human with acceptable efficiency," it should be distinguished from a typical embryo. ${ }^{212}$ However, this distinction seems inadequate under the personoriented theory to justify viewing an SCNT embryoid as less than a potential person. While SCNT embryoids and typical embryos share the potential to develop into live born offspring, both resulting offspring with disability or not share equal personhood. Therefore, we should not afford SCNT embryoids any lesser right than that afforded a traditional embryo.

Again, Landry and Zucker contend that researchers may determine the point at which the cell is unable to continue development by irreversible arrest of cell division and embryo death. ${ }^{213}$ However, irreversible arrest of cell division proves open to error since no definitive criteria exist. ${ }^{214}$ Hence,

\footnotetext{
${ }^{209}$ NATIONAL RESEARCH COUNCIL AND INSTITUTE OF MEDICINE, supra note 4, at 30.

${ }^{210} I d$. at 28 .

${ }^{211}$ Landry, supra note 3, at 1186.

${ }^{212}$ Jaenisch, supra note 140, at 2791.

${ }^{213}$ Landry, supra note 3 , at 1186.

${ }^{214}$ Id.
} 
depending on irreversible arrest of cell division may result in terminating an embryo that has the potential of developing into a live born human being. As for embryonic death as a defining feature, some embryos that have been deemed "dead" have been able to maintain their developmental potential. ${ }^{215}$ Thus, irreversible arrest of cell division and organismic "death" fail to provide satisfactory evidence for an embryo's loss of potential life.

Despite these various arguments for giving SCNT embyoids a lesser status than potential person or carefully selecting them for use in research, the embryoid's inherent ability to develop into a live person, regardless of its quality and quantity, merits the embryoid's status as a potential person. In which case, the person-oriented theory of special respect would similarly preserve the potential lives of SCNT embryoids, much like natural embryos. Thus, a state adopting the person-oriented theory of special respect would likely ban stem cell extractions from these embryoids, since such a procedure robs the SCNT embryoid of its potential for human life.

While a ban on destroying SCNT embryoids in the process of culturing stem cells appears necessary to show the potential person special respect, we must next consider whether the mere production of SCNT embryoids would remain consistent with the person-oriented theory. SCNT may serve purposes other than therapeutic cloning. For instance, through reproductive cloning, SCNT makes it possible to create offspring that are genetically identical to the donor. However, such use would still run contrary to the special respect due an SCNT embryoid and the preservation of human dignity, because "with larger numbers comes the possibility of declining regard." 216 The more replicas made; the less value an individual person will hold in society. Society may even go so far as to consider a person expendable, since his exact genetic makeup lives on in another human body.

Additionally, a ban on reproductive cloning will protect women who volunteer as surrogate mothers. While ninety-nine percent of embryoid blastocysts fail, many give way in later stages, which

\footnotetext{
${ }^{215} \mathrm{Id}$.

${ }^{216}$ Charo, supra note 14 , at 88.
} 
can harm the woman bearing the child in her womb. ${ }^{217}$ Banning SCNT altogether, including the production of embryoids for the purpose of creating a genetically identical offspring, would protect the interest of women volunteering their wombs for development. Already acknowledging ethical concerns over reproductive cloning, Congress passed the Human Cloning Prohibition Act and has prohibited reproductive cloning of humans and subjects violators to prison or a fine. ${ }^{218}$

Remaining consistent with this Act, special respect for SCNT embryoids and preservation of human dignity would demand a complete ban on SCNT embryo production. Because SCNT embryoids possess a capacity for human life, the person-oriented theory would entitle each embryoid to the chance at developing into a live born offspring. On the other hand, this would lead to reproductive cloning, which as we have determined - undermines special respect and human dignity. Hence, SCNT embryoids have no legitimate purpose in a state adopting the person-oriented theory of special respect. For this reason, such a state should entirely ban SCNT procedures.

As for the already-existing embryoids, a person-oriented theory would have to choose between two "evils." While embryoids can serve practical purposes of stem cell cultivation and reproductive cloning, the person-oriented theory will not permit such uses. The only other option would be to store the embryos in perpetuity. Still, continuous storage fails to satisfy the principle of giving each potential person the opportunity to fulfill its potential for human life. Hence, a state adopting the potential personhood theory would have to choose between using the embryoids in stem cell research or allowing reproductive cloning.

While using embryoids in stem cell research could benefit society through medical advances, a person-oriented state would more likely focus its attention on the embryoid as a potential person. Sticking with its central principle of protecting the embryoids' potential for human life and giving it a reasonable opportunity to come to fruition, the state would most likely allow reproductive cloning in the case of pre-existing embryoids. However, if reproductive cloning posed too great of a threat to the

\footnotetext{
${ }^{217}$ Weissman, supra note 114.

${ }^{218}$ Rhodes, supra note 130, at 342.
} 
surrogate mother, the state might keep the embryo in storage to avoid harming the existing surrogate and to abstain from completely destroying the embryoid. Still, where the surrogate mother willingly takes on the potential risks, the state might allow the embryoid's implantation and development. In all, the personoriented theory would generally result in a complete ban on SCNT with an exception for reproductive cloning in the case of pre-existing embryos.

\section{iii. Single Cell Biopsy of Eight-Cell Embryos}

In an innovative technique of single cell biopsies, scientists have tried to overcome the ethical problems of stem cell extraction, yet even this new procedure may prove inconsistent with the personoriented theory of special respect. In single cell biopsies, the eight-celled embryo from which the researcher extracts the single blastomere is a typical embryo capable of full development and live birth. After extraction, the remaining seven-celled embryo that is implanted in the womb typically develops into a live born baby. ${ }^{219}$ In contrast, the extracted blastomere is destroyed in the process of extracting stem cells.

In assessing the legitimacy of single cell biopsies under the person-oriented view, we must first determine which cells, if any, constitute a potential person and next whether the extraction of stem cells violates the concept of special respect. Clearly, the seven-celled embryo resulting from the procedure holds potential to develop into a live born offspring. In fact, physicians conducting PGD commonly implant the seven cells into the uterus, which then successfully develop into a living baby. Thus, the seven celled embryo is a potential person due special respect.

On the other hand, the inherent ability of the blastomere remains highly disputed. One of the founding researchers, Dr. Lanza, contends that individual human blastomeres have "never been shown to create viable embryos." ${ }^{220}$ Conversely, other scientists deem that a single human blastomere has the

\footnotetext{
${ }^{219}$ Stem Cell Side Shows, supra note 155. ${ }^{220} I d$.
} 
ability to further divide into a fully functional blastocyst. ${ }^{221}$ In which case, the blastomere holds inherent potential to mature into an actual person and has a right to special respect as a potential person. Amidst this debate, the status of the extracted blastomere as a potential person remains uncertain.

Next in considering the legitimacy of stem cell extraction from single cell biopsies, special respect under the person-oriented theory requires the protection of each entity's potential for human life. As for the seven-celled embryo, stem cell extraction refrains from impeding the embryo's ability to develop. Rather, the embryo is implanted and often results in a live born offspring. On the other hand, the cultivation of hES cells via single cell biopsies requires the manipulation of the removed blastomere. This process damages any ability that the blastomere may have held to develop into a live born offspring.

If the blastomere by itself possesses inherent potential for human life, then the extraction of stem cells from the biopsied blastomere would violate the person-oriented theory. Note this inherent potential does not require a high probability of occurrence, but simply calls for some prospect that a blastomere will grow into a live born offspring. While not every blastomere will survive past birth, the personoriented theory may have an interest in protecting the single blastomere that can intrinsically survive and mature into an actualized person. Since a researcher cannot differentiate the blastomere that will actualize into a born person and the blastomere that will not, protecting the potential person's capacity for life would require a complete prohibition of the procedure. Hence, if a state adopted the person-oriented understanding of special respect and a blastomere was shown to develop into a fully viable person, the state would likely bar the single cell biopsy method for stem cell extraction. This approach resonates with the sentiment that many approve of single cell biopsies as respectful of the potential life so long as the removed blastomere cannot inherently develop into an embryo and live offspring. ${ }^{222}$

Erring on the side of caution and showing the blastomere special respect, a state adopting the person-oriented theory may prohibit the single cell biopsy method for culturing hES cells even without direct evidence of a single blastomere developing to the point of viability. While some may contend that

\footnotetext{
${ }^{221}$ Kaplan, supra note 55.

${ }^{222}$ Wade, supra note 153.
} 
the probability of a single blastomere developing into a live born baby is so remote that it does not merit protection, the impact of the person-oriented theory depends not on the exactitude of probability, but instead on the possibility of human life. To protect the blastomere's potential for life; the person-oriented theory would preclude the practice of extracting stem cells from the blastomere, which destroys the cell and any capacity for human life.

An additional advantage to prohibiting single cell biopsies for hES cell cultures is decreased risk to the original embryo. ${ }^{223}$ Although some contend that a seven-celled embryo has virtually the same live birth success rate as an eight-celled embryo, ${ }^{224}$ blastomere extraction may put the original embryo at risk. While 2,000 babies have been born after extraction of a blastomere, the procedures may pose a risk of safety and long-term health on the embryo. ${ }^{225}$ Since the rate of ES cell cultures is 1 in 25 blastomeres, every one cell line puts 25 embryos at risk. ${ }^{226}$

Furthermore, a complete ban on the single cell biopsy method of cultivating stem cells would prevent an added demand for more stem cells. Aside from the lack of special respect shown to the extracted blastomere, additional concern arises in the production of hES cells that remain necessary for the procedure. ${ }^{227}$ Since the procedure requires additional hES cells, cultivating stem cells by the single cell biopsy method creates a market for stem cells. Initially, many of these hES cells will have to come from another source, and even after some time single cell biopsy stem cell cultivation may fail to produce sufficient stem cells needed for the procedure. This would force researchers to look to other sources for stem cells and possibly encourage destruction of embryos or embryoids in other methods of stem cell extraction. In effect, not relying on single cell biopsies may prevent a need for further embryonic destruction.

Finally, culturing stem cells from eight-cell embryos fails to provide the needed diversity in hES cell lines. Single cell biopsies only provide hES cell cultures that share their genetic makeup with current

\footnotetext{
${ }^{223}$ Stem Cell Side Shows, supra note 155.

${ }^{224}$ Kaplan, supra note 55.

${ }^{225}$ Stem Cell Side Shows, supra note 155.

${ }^{226}$ Kaplan, supra note 55.

${ }^{227}$ Id.
} 
or future embryos. ${ }^{228}$ The procedure lacks the capacity to produce stem cells that duplicate the genetics of an already existing person. ${ }^{229}$ As opposed to single cell biopsies, a method that produces stem cells genetically matching a living donor is more desirable as a therapeutic tool. Hence, a state could resolve the problems posed in prohibiting single cell biopsies by offering an even better resource of stem cells that researchers can also use in therapy for already viable people.

\section{v. Alternative Nuclear Transfer (ANT)}

As a solution, ANT offers a wide resource for stem cells that replicate the genetics of currently living people without extinguishing an embryoid's intrinsic ability to mature into a live born offspring. ANT embryoids inherently lack potential to develop into viable human babies. ${ }^{230}$ Still, they supply stem cells thatserve as therapeutic tools in regenerative medicine. ${ }^{231}$ Since hES cells from ANT embryoids are self-renewing and can be induced to differentiate into any tissue type, researchers may use them to study genetic illness and create methods to overcome tissue rejection. ${ }^{232}$ Not only do ANT embryoids offer therapeutic value for future people, but, by creating stem cells that duplicate the genetic makeup of fully viable humans, they also provide therapeutic value for already existing persons. While society has a great interest in accumulating large banks of genetically diverse hES cells, ANT embryoids provide scientists an invaluable source of stem cells without impeding a potential person's capacity for life. ${ }^{233}$

While the ANT embryoid cannot produce a live born offspring, it has no potential of becoming a person and thus retains no right to special respect. Hence, when ANT embryoids are dissected for purposes of extracting stem cells, the embryoid loses nothing. Since the ANT embryoid fails to possess the innate potential for human life, it falls short of a potential person worthy of special respect. Even if the ANT embryoid were presumed a potential person, it would still lack the innate potential for life that

\footnotetext{
${ }^{228}$ Stem Cell Side Shows, supra note 155.

${ }^{229} \mathrm{Id}$.

${ }^{230}$ Check, supra note 132.

${ }^{231}$ NATIONAL RESEARCH COUNCIL AND INSTITUTE OF MEDICINE, supra note 4, at 24, 28.

${ }^{232} \mathrm{Id}$. at 27-28.

${ }^{233}$ Id. at 28.
} 
special respect protects. Hence, culturing hES cells from ANT embryoids remains consistent with the theory that embryos capable of producing live born offspring constitute potential persons worthy of special respect, i.e. protection of their potential lives. In which case, a state taking on the person-oriented view would permit the extraction of stem cells from ANT embryoids.

In regulating such extractions, the government should require consent from the nucleus donor. The Omnibus Reconciliation Act of 1986 allows doctors to approach a person's next of kin for purposes of organ donation only after the individual has suffered brain death. ${ }^{234}$ Eric Cohen, an Ethics and Public Policy Center analyst in Washington D.C., calls ANT the "embryonic equivalent of brain death." ${ }^{, 235}$ This is consistent with the fact that an ANT embryoid will not achieve viability and has no capacity for human life. Hence, it seems most appropriate that similar to cases of brain death the government require some consent from the donor or next of kin. Though the embryoid is not a person or even a potential person, the nucleus donor would prove an appropriate decision-maker, either as the organ donor himself or the next of kin due to the donor's genetic connection to the embryoid. Therefore, requiring approval from the nucleus donor would prove reasonable in light of common organ donation practices.

While ANT offers a legitimate means of stem cell extraction within the person-oriented theory of special respect, some, including other members of the President's Council on Bioethics, refuse to consider the non-implantable product of ANT as constituting a nonviable artifact. ${ }^{236}$ Even so, unable to produce live born offspring, the ANT embryoid lacks potential personhood whether or not it constitutes a nonviable artifact. Though the abnormality does not appear until the onset of cdx 2 expression, the cell mass still remains inherently incapable of implantation, development, and live birth. ${ }^{237}$ Hence, under the theory that only potential persons merit special respect, ANT embryoids remain suitable for stem cell extraction.

\footnotetext{
${ }^{234}$ Landry, supra note 3, at 1185.

${ }^{235}$ Check, supra note 132

${ }^{236}$ Weissman, supra note 114

${ }^{237}$ Meissner, supra note 6, at 3.
} 
Although this alternative method for cultivating stem cells seems promising, scientists seek to use other current stem cell extraction methods until ANT works on human cells. Scientists contend that it is unwise and inefficient to create a complete moratorium on all other methods for culturing ES cells when ANT's applicability to human ES cells hangs in the balance. ${ }^{238}$ Although this is an economic argument, it fails to take into consideration the importance of showing a potential person due respect. While human dignity generally outweighs economic concerns, an embryo's interest to special respect would likely outweigh the scientific community's efficiency argument. Like the importance of preserving a person's fundamental rights outweighs economic efficiency, the concern of showing a potential person special respect outweighs mere convenience and prestige. Since preserving human dignity far outweighs the prestigious benefit of leading the scientific community, we should not allow fear of being left behind to drive legislation. $^{239}$ Theoretically, acceptance of a moratorium may even set a trend for other states and countries to follow. ${ }^{240}$

Beyond showing a potential person special respect, ANT also offers a reasonable compromise to the ethical debate over stem cell research, even in the Catholic Church. Though some members argue that any non-therapeutic experimentation on embryos is illicit whether or not it compromises the embryoid's life or integrity, ${ }^{241}$ others, such as Reverend Tacholczyk, ${ }^{242}$ call ANT “a step in the right direction. ${ }^{243}$ In August 2004, William Levada, one of the most prominent Catholics in the United States, wrote President Bush, encouraging consideration of ANT as a permissible method for culturing hES cells. ${ }^{244}$ Hence, permitting ANT stem cell extraction while prohibiting all other methods that impede an embryo's natural ability to mature into a viable human being, a state may bring some satisfaction to the different interest groups involved in the ethical debate.

\footnotetext{
${ }^{238}$ Wade, supra note 153

${ }^{239}$ Rhodes, supra note 130 at 360.

${ }^{240} \mathrm{Id}$.

${ }^{241}$ Congregation for the Doctrine of the Faith, supra note 19.

${ }^{242}$ Reverend Tacholczyk is the director of education for the National Catholic Bioethics Center in Philadelphia.

${ }^{243}$ Ritter, supra note 152.

${ }^{244} \mathrm{Id}$.
} 
Furthermore, once researchers extract stem cells from the ANT embryoid, the use of stem cells in therapeutic medicine does not contravene special respect for a potential person. As noted before, stem cells alone cannot inherently implant in the uterus and grow into a live born offspring. Like ANT embryoids, extracted stem cells are not potential persons, since they lack the inherent potential to develop into a viable human being. Even if they did constitute potential persons, neither ANT embryoids nor stem cells have an inherent capacity for human life that special respect would protect. In all, a state that adopts the person-oriented theory of potential personhood and special respect would likely approve stem cell extraction from ANT embryoids and the use of these stem cells in therapeutic medicine.

While stem cell derivation from ANT embryoids avoids impeding potential for human life, the procedure still requires oocyte donations. To reduce commodification of human life, the state may employ legislation similar to that mentioned in our discussion of IVF. For instance, the state might limit compensation for egg donors to the value of the donor's time and effort. ${ }^{245}$ An appropriate valuation would likely reflect minimum wage. By regulating financial solicitation for gamete donation, the state would prevent commodification of gametes, embryos, and human life.

Such legislation would also reduce continuing risks to oocyte donors. Instead of disregarding the risks of oocyte donation, donors would prove more inclined to weighing the dangers before agreeing to donation. This especially protects the interest of the economically challenged woman who might be unduly influenced by high compensation. Overall, though ANT perpetuates the continual need for oocyte donation, it still allows stem cell extraction without disrespecting a potential person and, with some regulation of financial solicitation, minimizes the harm to gamete donors.

${ }^{245}$ Ethics Committee of the American Society for Reproductive Medicine, supra note 38, at 219. 


\section{CONCLUSION}

In conclusion, the status of embryos has been highly disputed as person or property, but a middle ground approach of potential personhood proves to be a more appropriate characterization of embryos. With the concept of potential personhood, comes treating embryos with special respect. This special respect may range from property-oriented treatment that limits an owner's property rights to personoriented treatment that preserves the embryo's capacity for life. Within this spectrum of interpreting special respect, societal conceptions of embryos and the interest of human dignity supports an approach more person-oriented than property-oriented.

If a state were to adopt potential personhood and a person-oriented understanding of special respect, this characterization of embryos would have a profound effect on medical procedures that require the use of embryos. Still, it would allow for a regulated use of in vitro fertilization and stem cell research. While defining special respect in a person-oriented manner requires protection of a potential person's capacity to develop into a live born offspring, such respect still permits use that does not destroy potential human life. So long as IVF patients limit the number of embryos produced to the number they desire to bear and make alternative plans of adoption for those they choose not to implant, IVF effectively preserves the embryo's inherent potential for life.

On the other hand, stem cell extraction methods may prove more problematic. The extraction of stem cells from regular embryos and SCNT embryoids eliminates the potential person's capacity to mature into an actual person. Thus, the person-oriented understanding of special respect would preclude such extractions. Similarly, taking stem cells from a single blastomere of an eight-celled embryo destroys any pre-existing capacity for human life that the blastomere held, which means special respect would likely prohibit this method. Still, in the end, ANT embryoids cannot create fully viable human beings in their natural development. Without the requisite potential for human life, ANT embryoids are not potential persons worthy of special respect. Therefore, researchers may freely destroy ANT embryoids without failing to protect potential human life. 
While a state that classifies an embryo as a potential person would still permit IVF and ANT stem cell extraction, the state may additionally regulate financial solicitation for gamete donations. Though gametes lack potential personhood, they closely relate to humanity as the basic components of human life. By restricting compensation, states prevent commodification of humans and reduce the harm to oocyte donors. In all, by closely regulating the use of embryos and gamete donation, a state may preserve human dignity and still allow IVF and stem cell research without extinguishing a potential person's capacity to develop into a live born offspring. 